\title{
Mechanism of Action of Sodium Hypochlorite
}

\author{
Carlos ESTRELA ${ }^{1}$ \\ Cyntia R.A. ESTRELA ${ }^{1}$ \\ Eduardo Luis BARBIN ${ }^{2}$ \\ Júlio César E. SPANÓ2 \\ Melissa A. MARCHESAN ${ }^{2}$ \\ Jesus D. PÉCORA² \\ ${ }^{1}$ Faculty of Dentistry, Federal University of Goiás, Goiânia, GO, Brazil \\ ${ }^{2}$ Faculty of Dentistry of Ribeirão Preto, University of São Paulo, Ribeirão Preto, SP, Brazil
}

\begin{abstract}
The choice of an irrigating solution for use in infected root canals requires previous knowledge of the microorganisms responsible for the infectious process as well as the properties of different irrigating solutions. Complex internal anatomy, host defenses and microorganism virulence are important factors in the treatment of teeth with asymptomatic apical periodontitis. Irrigating solutions must have expressive antimicrobial action and tissue dissolution capacity. Sodium hypochlorite is the most used irrigating solution in endodontics, because its mechanism of action causes biosynthetic alterations in cellular metabolism and phospholipid destruction, formation of chloramines that interfere in cellular metabolism, oxidative action with irreversible enzymatic inactivation in bacteria, and lipid and fatty acid degradation. The aim of this work is to discuss the mechanism of action of sodium hypochlorite based on its antimicrobial and physico-chemical properties.
\end{abstract}

Key Words: sodium hypochlorite, irrigating solution, intracanal dressing.

\section{INTRODUCTION}

The agents responsible for microbial control in endodontic infections have been studied in different health areas. There is significant research about biologic reactions to microbial virulence factors (representing pathogenic degree) and immunologic factors (host defense responses). The selection of effective microbial control of infected root canals requires detailed knowledge of the microorganisms responsible for pulp and periapical pathology associated with knowledge of the mechanism of action of the antimicrobial solution.

Microorganisms that compose endodontic microbiota were isolated and identified after the development of modern collection and transport techniques for its culture $(1,2)$. It was then confirmed that infections of root canals are mixed, with predominantly Gram-negative anaerobic bacteria. Antimicrobial agents must suppress or destroy microbial growth; thus susceptibility of the microorganisms, penetration of anti- microbial agent to the infected site, adequate concentration of the agent, low toxicity to the host cells, lack of microorganism development of resistance to the agent are necessary.

The process of reducing or eliminating the microbiota of infected root canals with apical periodontitis has been studied (3-6), reporting the importance of complex inner anatomy, the dynamic relation of the microorganism and factors related to host response. This process is begun during root canal preparation with chemical agents and the use of an intracanal dressing that aids in success of this process $(3,5)$.

Different auxiliary chemical agents for root canal preparation have been proposed and the most commonly used in endodontics is sodium hypochlorite (712). An effective irrigating solution in root canal preparation is essential for the sanitization process because it favors cleaning and shaping and neutralizes necrotic content which favors root canal enlargement for subsequent filling.

Thus, considering the necessity of sodium hy- 
pochlorite as an auxiliary irrigating solution during infected root canal preparation, it is essential to understand the mechanism of action of this substance.

\section{SODIUM HYPOCHLORITE PROPERTIES}

The worldwide use of sodium hypochlorite as a root canal irrigating solution is due mainly to its efficacy for pulpal dissolution and antimicrobial activity. A less concentrated solution, such as $1 \%$ sodium hypochlorite, presents acceptable biological compatibility.

Pécora et al. (7) reported that sodium hypochlorite exhibits a dynamic balance as is shown by the reaction:

$\mathrm{NaOCl}+\mathrm{H}_{2} \mathrm{O} \leftrightarrow \mathrm{NaOH}+\mathrm{HOCl} \leftrightarrow \mathrm{Na}^{+}+\mathrm{OH}^{-}+\mathrm{H}^{+}+\mathrm{OCl}^{-}$

The chemical reactions verified between organic tissue (7,10-12) and sodium hypochlorite are shown in

Scheme 1. Saponification reaction.

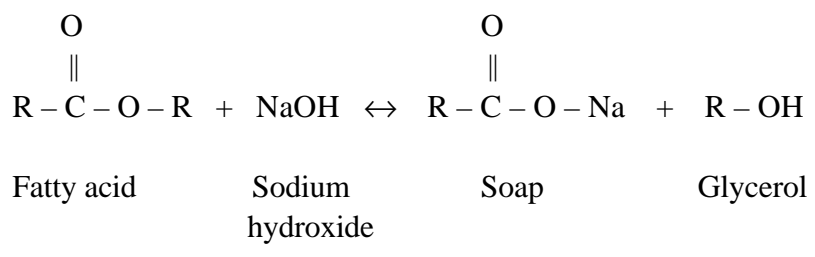

Scheme 2. Amino acid neutralization reaction.

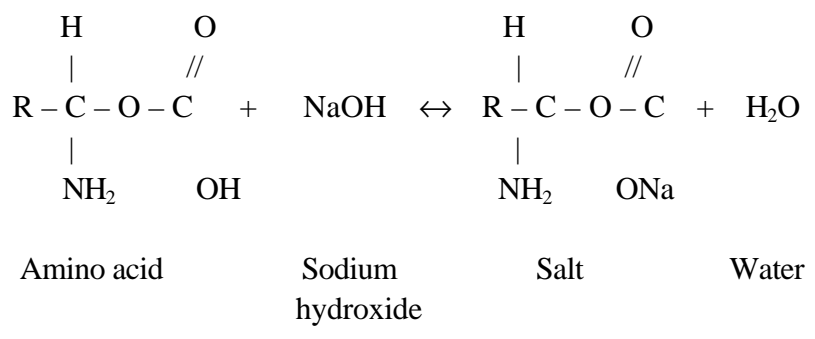

Scheme 3. Chloramination reaction.

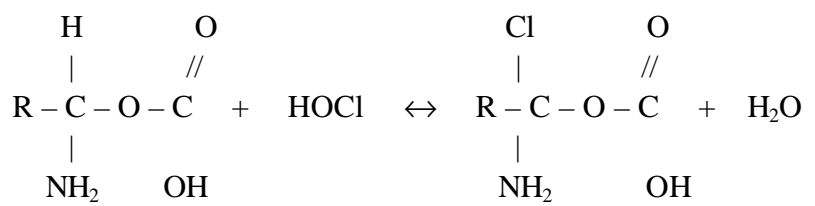

Amino acid Hypochlorous Chloramine Water acid schemes 1-3.

Interpreting these chemical reactions, it can be observed that sodium hypochlorite acts as an organic and fat solvent degrading fatty acids, transforming them into fatty acid salts (soap) and glycerol (alcohol), that reduces the surface tension of the remaining solution (scheme 1 - saponification reaction).

Sodium hypochlorite neutralizes amino acids forming water and salt (scheme 2 - neutralization reaction). With the exit of hydroxyl ions, there is a reduction of $\mathrm{pH}$. Hypochlorous acid, a substance present in sodium hypochlorite solution, when in contact with organic tissue acts as a solvent, releases chlorine that, combined with the protein amino group, forms chloramines (scheme 3 - chloramination reaction). Hypochlorous acid $\left(\mathrm{HOCl}^{-}\right)$and hypochlorite ions $\left(\mathrm{OCl}^{-}\right)$lead to amino acid degradation and hydrolysis.

The chloramination reaction between chlorine and the amino group (NH) forms chloramines that interfere in cell metabolism. Chlorine (strong oxidant) presents antimicrobial action inhibiting bacterial enzymes leading to an irreversible oxidation of SH groups (sulphydryl group) of essential bacterial enzymes.

Considering the physico-chemical properties of sodium hypochlorite when in contact with organic tissue, these reactions can be verified. Sodium hypochlorite is a strong base $(\mathrm{pH}>11)$. At $1 \%$ concentration, sodium hypochlorite presents a surface tension equal to 75 dynes/cm, stickiness equal to $0.986 \mathrm{cP}, 65.5 \mathrm{mS}$ of conductivity, $1.04 \mathrm{~g} / \mathrm{cm}^{3}$ of density and moistening capacity equal to $1 \mathrm{~h}$ and $27 \mathrm{~min}$. Its antimicrobial mechanism of action can be observed verifying its physico-chemical characteristics and its reaction with organic tissue.

Considering knowledge of $\mathrm{pH}$ processes and isolated activities in essential enzymatic sites, such as those in the membrane, it is enlightening to associate sodium hypochlorite (high $\mathrm{pH}$, over 11), to harmful biological effects on bacterial cells in order to explain one part of its mechanism of action.

Estrela et al. (13) studied the biological effect of $\mathrm{pH}$ on the enzymatic activity of anaerobic bacteria. Because enzymatic sites are located in the cytoplasmic membrane, which is responsible for essential functions such as metabolism, cellular division and growth, and take part in the last stages of cellular wall formation, biosynthesis of lipids, transport of electrons and oxidative phosphorylation, the authors believe that hydroxyl 
ions from calcium hydroxide develop their mechanism of action in the cytoplasmic membrane. Extracellular enzymes act on nutrients, carbohydrates, proteins, and lipids that, through hydrolysis, favor digestion. Intracellular enzymes located in the cell favor respiratory activity of the cellular wall structure. The $\mathrm{pH}$ gradient of the cytoplasmic membrane is altered by the high concentration of hydroxyl ions of calcium hydroxide acting on the proteins of the membrane (proteic denaturation). The high $\mathrm{pH}$ (12.5), influenced by the release of hydroxyl ions, alters the integrity of the cytoplasmic membrane by means of chemical injuries to organic components and transport of nutrient, or by means of the degradation of phospholipids or unsaturated fatty acids of the cytoplasmic membrane, observed in the peroxidation process, which is a saponification reaction (14).

The antimicrobial effectiveness of sodium hypochlorite, based in its high $\mathrm{pH}$ (hydroxyl ions action), is similar to the mechanism of action of calcium hydroxide. The high $\mathrm{pH}$ of sodium hypochlorite interferes in the cytoplasmic membrane integrity with an irreversible enzymatic inhibition, biosynthetic alterations in cellular metabolism and phospholipid degradation observed in lipidic peroxidation.

The amino acid chloramination reaction (reaction 3) forming chloramines interferes with cellular metabolism. Oxidation promotes irreversible bacterial enzymatic inhibition replacing hydrogen with chlorine. This enzyme inactivation can be observed in the reaction of chlorine with amino groups $\left(\mathrm{NH}_{2}^{-}\right)$and an irreversible oxidation of sulphydryl groups $(\mathrm{SH})$ of bacterial enzymes (cystein).

Thus, sodium hypochlorite presents antimicrobial activity with action on bacterial essential enzymatic sites promoting irreversible inactivation originated by hydroxyl ions and chloramination action. Dissolution of organic tissue can be verified in the saponification reaction when sodium hypochlorite degrades fatty acids and lipids resulting in soap and glycerol.

Some physico-chemical characteristics must be mentioned. Grossman and Meiman (15), observing pulp tissue dissolution capacity, reported that $5 \%$ sodium hypochlorite dissolves this tissue in $20 \mathrm{~min}$ to $2 \mathrm{~h}$. The dissolution of bovine pulp tissue by sodium hypochlorite $(0.5,1.0,2.5,5.0 \%)$ was studied in vitro under different conditions (10-12). It was concluded that: 1) the velocity of dissolution of the bovine pulp fragments was directly proportional to the concentration of the sodium hypochlorite solution and was greater without the surfactant $(10)$; 2) the variation of surface tension, from beginning to end of pulp dissolution, was directly proportional to the concentration of the sodium hypochlorite solution and was greater in the solutions without surfactant. Solutions without surfactant presented a decrease in surface tension and those with surfactant an increase (10); 3) with the elevation of temperature of the sodium hypochlorite solutions, dissolution of the bovine pulp tissue was more rapid (11); 4) the percent variation of the sodium hypochlorite solutions, after dissolution, was inversely proportional to the initial concentration of the solution, or in other words, the greater the initial concentration of the sodium hypochlorite solutions, the smaller was the reduction of its $\mathrm{pH}$ (12).

\section{DISCUSSION}

The greatest concern in the selection of any irrigant solution or medication is the knowledge of its mechanism of action on the predominant bacterial microflora. Knowledge about morphology, structure and physiology of microorganisms that are responsible for pain and destruction of periapical tissues led to several therapeutic trends. The first step of endodontic treatment is the knowledge of the interrelation between microorganisms and host, together with the chemical and biological dynamics of antimicrobial medications.

Root canal preparation and the use of irrigating solutions such as sodium hypochlorite is responsible for eliminating the majority of microorganisms in an infected root canal system $(4,5)$. However, the use of intracanal dressings is essential to eliminate surviving microorganisms $(3,5)$. Calcium hydroxide has been the most used and studied intracanal dressing $(5,6)$.

Sodium hypochlorite is recommended and used by the majority of dentists because this solution presents several important properties: antimicrobial effect $(3,4,16)$, tissue dissolution capacity $(1-12,15)$ and acceptable biologic compatibility in less concentrated solutions $(17,18)$. In relation to antimicrobial effect, studies have shown that sodium hypochlorite decreases microorganism number during the treatment of teeth with apical periodontitis $(3,4)$.

Estrela (16) studied the efficacy of root canal irrigating solutions (1,2 and 5\% sodium hypochlorite, 
$2 \%$ chlorhexidine digluconate, $1 \%$ calcium hydroxide, and HCT20, a solution of calcium hydroxide associated with a detergent) on $S$. aureus, E. faecalis, P. aeruginosa, B. subtilis, $C$. albicans and a mixture of these microorganisms. The purpose was to determine the minimum inhibitory concentration of the tested solutions with a serial dilution in the proportion of $1: 10$, and antimicrobial activity with direct exposure at 5, 10, 15, 20 and 30 min. It was concluded that the minimum concentration of $1 \%$ sodium hypochlorite required for inhibiting $S$. aureus, E. faecalis, $P$. aeruginosa and $C$. albicans was $0.1 \%$, and $1 \%$ for $B$. subtilis and for the mixture. All microorganisms were inactivated by this solution at all experimental periods $(5,10,15,20$ and $30 \mathrm{~min})$. The minimum concentration of $2 \%$ sodium hypochlorite required for inhibiting $S$. aureus, E. faecalis, $P$. aeruginosa and $C$. albicans was $0.2 \%$, and $2 \%$ for $B$. subtilis and for the mixture. All microorganisms were inactivated by this solution at all experimental periods. The minimum concentration of 5\% sodium hypochlorite required for inhibiting all microorganisms was $0.5 \%$, at all time periods. Chlorhexidine digluconate (2\%) showed minimum inhibitory concentration of $0.000002 \%$ for $S$. aureus, $0.002 \%$ for P. aeruginosa, $0.02 \%$ for E. faecalis, B. subtilis, C. albicans and the mixture. Antimicrobial effectiveness in the direct exposure test was observed at all experimental periods for $S$. aureus, E. faecalis and C. albicans, but it was ineffective for P. aeruginosa, B. subtilis and for the mixture at all periods. Calcium hydroxide solution $(1 \%)$ showed minimum inhibitory concentration equal to $1 \%$ for $P$. aeruginosa but was not effective against the other microorganisms. The antimicrobial activity by direct exposure test was evident against $S$. aureus, E. faecalis and $P$. aeruginosa after $30 \mathrm{~min}$, although it was not effective against $B$. subtilis, $C$. albicans and the mixture at all periods analyzed in this study. The solution of calcium hydroxide associated with a detergent (HCT20) showed minimum concentration ineffective against $E$. faecalis, and total concentration (100\%) over the other microorganisms. In the direct exposure test, the effectiveness was observed after $20 \mathrm{~min}$ for $S$. aureus and 30 min for E. faecalis. This solution was not effective against $P$. aeruginosa, B. subtilis, $C$. albicans and the mixture.

Sodium hypochlorite presents high surface tension (75 dynes/cm) and minimum inhibitory concentration lower than $1 \%$ for resistant microorganisms $(S$. aureus, E. faecalis, P. aeruginosa, B. subtilis and $C$. albicans). The concentration rise is directly proportional to the antimicrobial effect and tissue dissolution capacity and inversely proportional to biologic compatibility. Thus, considering the high surface tension and that antimicrobial action can be achieved with the less concentrated solution, the better option is $1 \%$ sodium hypochlorite.

Physico-chemical characteristics of sodium hypochlorite are important for the explanation of its mechanism of action. The saponification, amino acid neutralization and chloramination reactions that occur in the presence of microorganisms and organic tissue lead to the antimicrobial and tissue dissolution process. The antimicrobial activity is related to bacterial essential enzymatic sites promoting irreversible inactivation by hydroxyl ions and the chloramination reaction. The organic dissolution action can be observed in the saponification reaction when sodium hypochlorite degrades lipids and fatty acids resulting in the formation soap and glycerol.

Sodium hypochlorite in higher concentrations is more aggressive while in lower concentrations $(0.5 \%$ to $1 \%$ ), it is biocompatible (17). For a substance to be biocompatible, it must present no or only a discreet tissue reaction at all periods and moderate or intense tissue reaction at 7 days which decreases in intensity with time until reaching a non-significant tissue reaction (18).

Additional studies must be carried out with other irrigating solutions in order to understand these and other properties.

\section{RESUMO}

Estrela C, Estrela CRA, Barbin EL, Spanó JCE, Marchesan MA, Pécora JD. Mecanismo de ação do hipoclorito de sódio. Braz Dent J 2002;13(2):113-117.

A seleção da solução irrigadora para uso em canais radiculares infectados impõe prévio conhecimento dos microrganismos responsáveis pela instalação do processo infeccioso, bem como as diferentes propriedades da substância irrigadora. Entre os obstáculos a serem vencidos no tratamento de dentes com periodontites apicais assintomáticas está a complexa anatomia interna, a virulência microbiana e as defesas do hospedeiro. Para a efetiva ação, em detrimento das condições encontradas no canal radicular, é essencial a solução irrigadora apresentar expressiva atividade antimicrobiana e adequada capacidade de dissolução tecidual. O hipoclorito de sódio tem sido eleito como solução irrigadora para uso endodôntico pela maioria dos 
profissionais. Este fato se deve ao mecanismo de ação desta solução irrigadora, capaz de promover alterações celulares biossintéticas, alterações no metabolismo celular e na destruição de fosfolipídios, pela formação de cloraminas que interferem no metabolismo celular, pela ação oxidante, com inibição enzimática irreversível nas bactérias, e pela degradação de ácidos graxos e lipídeos. O objetivo deste estudo é discutir o mecanismo de ação do hipoclorito de sódio a partir de suas propriedades físicoquímicas e antimicrobianas.

Unitermos: hipoclorito de sódio, soluções irrigantes, medicação intracanal.

\section{REFERENCES}

1. Sundqvist G. Taxonomy, ecology and pathogenicity of the root canal flora. Oral Surg Oral Med Oral Path 1994;78:522-530.

2. Nair PNR. Apical periodontites: a dynamic encounter between root canal infection and host response. Periodontol 2000;1997:13:121-48.

3. Byströn A, Sundqvist G. Bacteriologic evaluation of the efficacy of mechanical root canal instrumentation in endodontic therapy. Scand J Dent Res 1981;89:321-328.

4. Byströn A, Sundqvist G. Bacteriologic evaluation of the effects of $0.5 \%$ sodium hypochlorite in endodontic therapy. Oral Surg Oral Med Oral Pathol 1983;55:307-312.

5. Estrela C, Bammann LL. Medicação Intracanal. In: Endodontia Princípios biológicos e mecânicos. Estrela C, Figueiredo JAP. Eds. São Paulo: Artes Médicas; 1999. p 572-653.

6. Estrela C, Bammann LL, Pimenta FC, Pecora JD. Control of microorganisms by calcium hydroxide pastes. Int Endod $\mathbf{J}$ 2001;34:341-345.

7. Pecora JD, Sousa-Neto MD, Estrela C. Soluções irrigadoras auxiliares do preparo do canal radicular. In: Endodontia Princípios biológicos e mecânicos. Estrela C, Figueiredo JAP. Eds. São Paulo: Artes Médicas; 1999. p 552-569.

8. Pecora JD, Costa WF, Campos GM, Roselino RB. Presentation of a histochemical method for the study of root dentine permeabil- ity. Rev Odont USP. Bauru 1987;1:3-9.

9. Pécora JD, Sousa Neto MD, Saquy PC, Silva RG, Cruz Filho AM. Effect of Dakin's and EDTA solutions on dentin permeability of root canals. Braz Dent J 1993; 4:79-84.

10. Barbin EL. Estudo "in vitro" do efeito da adição de lauril dietileno glicol éter sulfato de sódio nas soluções hipoclorito de sódio sobre suas propriedades físico-químicas anteriores e posteriores à dissolução do tecido pulpar bovino. [Master's thesis]. Ribeirão Preto: University of São Paulo; 1999. 108p. Internet site: http:// www.forp.usp.br/restauradora/Teses/Barbin/mestrado_barbin.html

11. Santos TC. Estudo "in vitro" do efeito do aumento da temperatura nas soluções de hipoclorito de sódio sobre suas propriedades físico-químicas anteriores e posteriores à dissolução do tecido pulpar bovino. [Master's thesis]. Ribeirão Preto: University of São Paulo; 1999. 108p. Internet site: http://www.forp.usp.br/ restauradora/Teses/Tanit/tanit_mestrado.html

12. Spanó JCE, Barbin EL, Santos TC, Guimarães LF, Pécora JD Solvent action of sodium hypochlorite on bovine pulp and physico-chemical properties of resulting liquid. Braz Dent $\mathbf{J}$ 2001;12:154-157.

13. Estrela C, Sydney GB, Bammann LL, Fellipe Jr O. Estudo do efeito biológico do $\mathrm{pH}$ na atividade enzimática de bactérias anaeróbias. Rev Fac Odontol Bauru 1994:2:29-36.

14. Estrela C, Sydney GB, Bammann LL, Felippe Jr O. Mechanism of action of calcium and hydroxyl ions of calcium hydroxide on tissue and bacteria. Braz Dent J 1995:6:85-90.

15. Grossman LI, Meiman BW. Solution of pulp tissue by chemical agent. J Amer Dent Ass 1941;28:223-225.

16. Estrela CRA. Eficácia antimicrobiana de soluções irrigadoras de canais radiculares. [Master's thesis]. Goiânia: Federal University of Goiás; 2000. 80p. Internet site: http://estrela.neomundi.com.br/

17. Holland R, Soares IJ, Soares IM. Influence of irrigation and intracanal dressing on the healing process of dog's teeth with apical periodontitis. Endod Dent Traumatol 1992:8:223-229.

18. Costa CAS. Teste de biocompatibilidade dos materiais odontológicos. In: Metodologia Científica: ensino e pesquisa em odontologia. Estrela C. Ed. São Paulo: Artes Médicas; 2001. p 161-194.

Accepted January 23, 2002 